\title{
Resveratrolün Kardiyovasküler Hastalıklar Üzerine Etkileri
}

\author{
Effects of Resveratrol on Cardiovascular Diseases
}

\section{Enver Çıracı ${ }^{1}$, Tuğçe Kalafat ${ }^{2}$}

Geliş tarihi/Received: 23.06.2020 • Kabul tarihi/Accepted: 15.04.2021

\section{ÖZET}

Kardiyovasküler hastalıklar; dünyada mortalitenin önde gelen nedenlerinden biridir. Kardiyovasküler hastalıkların önlenmesi ve uygulanan tedavilerin etkisinin arttırılmasında, doğal nutrasötikleri kullanan alternatif farmakoterapi yöntemleri oldukça umut vericidir. Potansiyel olarak, kardiyovasküler hastalıkların tedavi edilmesine yardımcı olduğu ve gelişimlerini önlediği düşünülen bu doğal bileşiklerden biri de resveratroldür. Resveratrol gibi biyoaktif diyet bileşenlerinin birden fazla hücresel hedefinin olduğu düşünülmektedir. Bu nedenle kardiyoprotektif, antioksidan, antikanser, antiinflamatuvar, antidislipidemik ve antidiyabetik olmak üzere birçok etkisi bulunabilir. Çeşitli bitkilerde doğal olarak bulunan resveratrol (trans-3,4',5 trihidroksistilben, RES), mantar saldırısına veya yaralanmaya yanıt olarak üretilen stilbenoid grubuna ait, flavonoid olmayan bir polifenoldür. Üzüm, kırmızı şarap, çilek ve yer fistığı gibi çeşitli besinlerde bulunmaktadır. Bu derlemede, resveratrolün koruyucu kardiyovasküler etkileri hakkında yakın zamanda yayınlanan temel araştırmaların sunulması hedeflenmektedir. Ortaya konulan çıkarımların hastalarda yeni klinik / terapötik stratejilerin gelişmesine katkı sağlaması amaçlanmıştır.

Anahtar kelimeler: Resveratrol, kardiyovasküler hastalıklar, polifenoller

\begin{abstract}
Cardiovascular diseases is one of the leading causes of mortality in the world. Alternative pharmacotherapy methods using natural nutraceuticals are very promising in preventing cardiovascular diseases and increasing the effect of the treatments applied. One of these natural compounds that are thought to potentially help to treat cardiovascular diseases and prevent their development is resveratrol. Bioactive dietary components such as resveratrol are thought to have more than one cellular target. Therefore, they may have many effects including cardioprotective, antioxidant, anticancer, anti-inflammatory, antidyslipidemic and antidiabetic. Resveratrol (trans-3,4,5 trihydroxystylbene, RES) naturally found in various plants is a non-flavonoid polyphenol belonging to the stilbenoid group produced in response to fungal attack or injury. It is found in a variety of foods such as grapes, red wine, strawberries and peanuts. In this review, it is aimed to present the basic research published recently on the protective cardiovascular effects of resveratrol. The revealed implications are intended to contribute to the development of new clinical / therapeutic strategies in patients.
\end{abstract}

Keywords: Resveratrol, cardiovascular disease, polyphenols

1. İletişim/Correspondence: Biruni Üniversitesi, Eczacllık Fakültesi, Biyokimya Ana Bilim Dal, İstanbul, Türkiye

E-posta: eciraci@biruni.edu.tr • ๑ https://orcid.org/0000-0001-9222-8464
2. Biruni Üniversitesi Lisansüstü Ĕ̆itim Enstitüsü, Beslenme ve Diyetetik Anabilimdall, İstanbul, Türkiye • ๑ https://orcid.org/0000-0002-9253-1137 


\section{GİRIŞ}

Kardiyovasküler hastalıklar (KVH) çocukluktan itibaren başlayan ve sinsice ilerleyen, belirtiler ortaya çıktığında ise genellikle ileri aşamaya gelmiş olan kronikleşmiş hastalıklardır. Koroner arter hastalığı, ölümlerin önde gelen küresel nedenidir (1). KVH'ın oluşumunda; sağlıksız beslenme alışkanlıkları, yetersiz fiziksel aktivite düzeyi, tütün ve aşırı alkol kullanımı gibi çeşitli önlenebilir risk faktörleri rol oynamaktadır (2).

Doğal nutrasötikleri kullanan alternatif farmakoterapinin, kardiyovasküler hastalıkların önlenmesi ve uygulanan tedavilerin etkisinin arttırılmasındaki rolleri araştırılmaktadır. RES (3,5,4'5-trihidroksistilben) üzüm, çilek, yer fıstığı ve insan beslenmesinin bir parçası olarak yaygın olarak tüketilen diğer besinlerde bol miktarda bulunan flavonoid olmayan bir polifenolik bileşiktir. Polifenoller, yaralanma, mantar enfeksiyonları veya ultraviyole ışılaması gibi eksojen stres faktörlerine yanıt olarak bitkilerde üretilir (3). Sağllk üzerine olumlu etkileri olduğu bilinen RES'in birçok potansiyel etki mekanizması tanımlanmıştır. RES'in; kardiyoprotektif, antioksidan, antikanser, nöroprotektif, antiinflamatuvar, antidislipidemik ve antidiyabetik olması insan sağlığında olumlu etkiler oluşturur (4). Resveratrol takviyesinin koroner kalp hastalığı riskini azaltabileceğini ve serum lipitlerini iyileştirebileceğine yönelik çalışmalar mevcuttur (1013).

$\mathrm{Bu}$ derlemede, resveratrolün kardiyovasküler hastalıklar üzerindeki koruyucu etkileri hakkında yayınlanmış temel araştırmaların sunulması hedeflenmekte olup, elde edilen sonuçların hastalarda yeni klinik terapötiklerin gelişmesine yol açabileceği ile ilgili detaylı bilgi verilmesi amaçlanmıştır.

\section{Resveratrol}

Doğal, flavonoid formda olmayan ve polifenol bir bileşik olan resveratrol (trans-3,4',5-trihidroksistilben) bir etilen köprüsü ile birbirine bağlı iki fenol halkasına sahip olan polifenollerin stilbenoid grubuna aittir
$(4,5)$. Fiziksel ve kimyasal özelliklerine göre, kapalı formülü $\mathrm{C}_{14} \mathrm{H}_{12} \mathrm{O}_{3}$ olan RES, beyazımsı ve toz halinde olan katı bir moleküldür. Molekül ağırlığı 228.25 g/ mol iken; erime noktası $253-255^{\circ} \mathrm{C}$ 'dir (6). Cis ve trans olmak üzere iki optik izomeri bulunmaktadır (Şekil 1) (7).
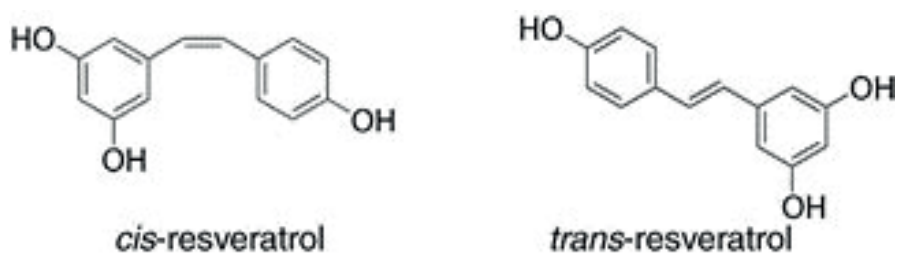

Şekil 1. Resveratrolün kimyasal yapısı (7).

Resveratrol, ilk olarak 1939 yllında Takaoka tarafindan beyaz hellebore (Veratrum grandiflorum O. Loes) bitki köklerinden izole edilmiştir (8). Daha sonra 1963 yılında kökleri, geleneksel Çin ve Japon tıbbında antiinflamatuvar ve antitrombosit ajanı olarak kullanilan Polygonum cuspidatum bitkisinden izole edilmiştir (9).

\section{Resveratrolün Biyosentezi}

Sınırlı sayıda bitki (yaklaşık 31 cins) tarafındanüretilen RES, fitoaleksin adı verilen savunma molekülleri sinıfına ait bir bileşiktir (14). RES, ultraviyole (UV) ışık radyasyonu ve doku bozulması gibi biyotik ve abiyotik stres koşullarında, $V$. vinifera yapraklarında gelişen Plasmopara viticola mantar enfeksiyonlarına karşı, fenilpropanoid yolunu kullanılarak yüksek bitki türlerinde sentezlenmektedir $(15,16)$.

Bitkilerde, resveratrolün biyosentezi fenilpropanoid yolağını içerir. Şikimat yolağındaki fenilalanin, fenilalanin amonyak liyaz (PAL) tarafindan sinnamik aside dönüştürülür. Sinnamik asit 4 hidroksilaz $(\mathrm{C} 4 \mathrm{H})$, sinnamik asidin hidroksi türevi olan p-kumarik aside dönüşümünü katalize eder, bu da 4-kumarat koenzim A (CoA) ligaz (4CL) tarafindan p-kumaril-CoA'ya dönüştürülür. P-kumaril-CoA'nin yoğunlaşması stilben sentaz (STS) ile üç eşdeğer malonil-CoA ile resveratrole siklize edilen bir tetraketid ara ürününe yol açar (Şekil 2) (17). 

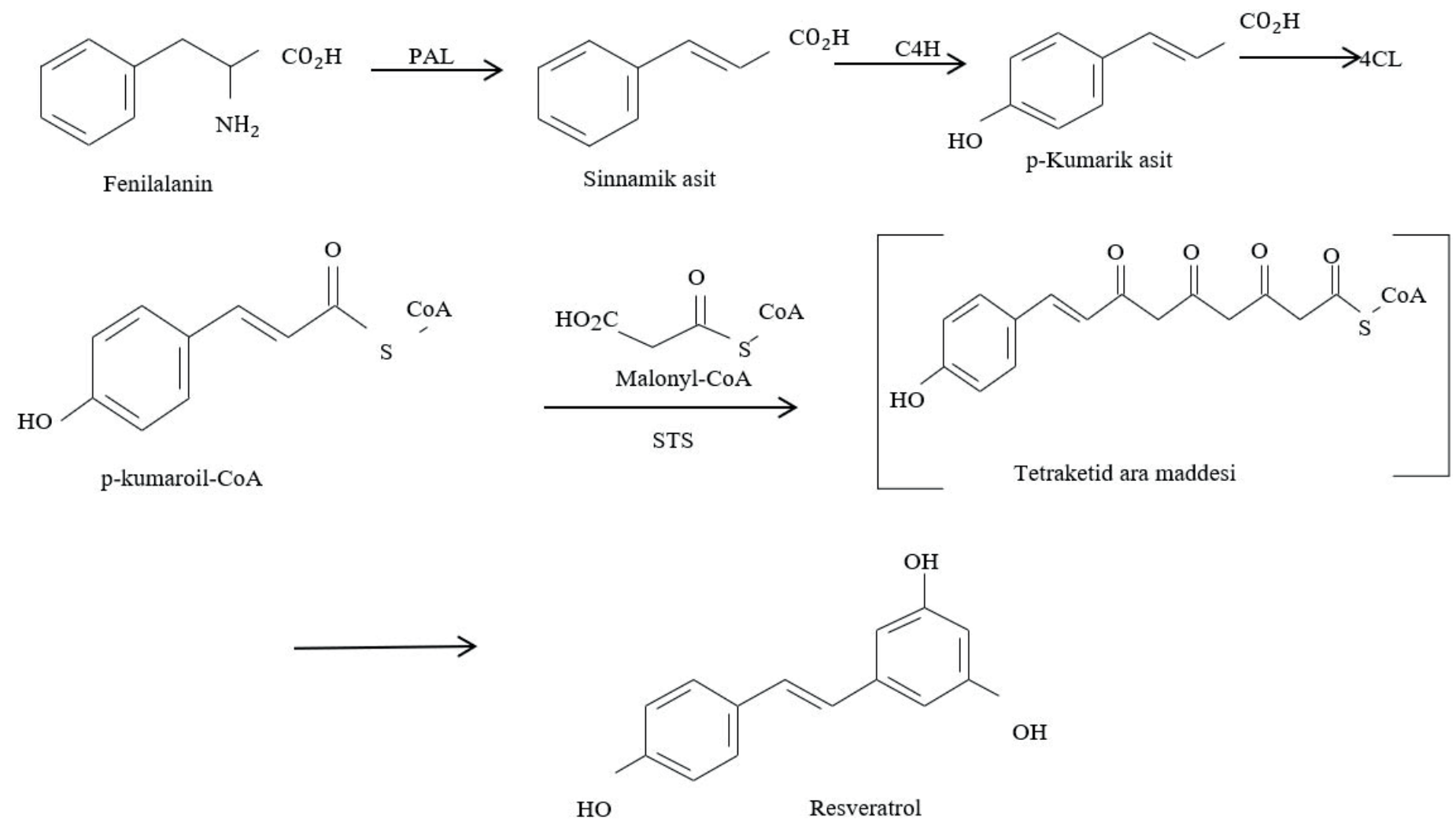

Şekil 2. RES'in biyosentezi (17).

\section{Resveratrolün Besin Kaynakları}

Doğada 100'den fazla bitkide bulunmakla birlikte, bu bitkilerin sadece birkaçı yenilebilir RES kaynağı olarak tanımlanabilir (19). Farklı kaynaklarda bulunan RES miktarı; çeşit, iklim, mantar enfeksiyonları, ultraviyole (UV) maruziyeti ve şarap yapım prosedürleri gibi faktörlere bağlı olarak değişmektedir (20). Üzüm, çilek, yer fıstığı ve kırmızı şarapta önemli miktarlarda RES bulunmaktadır (7). Bunlardan biri olan kırmızı şarap, üretildiği üzümün kabuğundaki yüksek konsantrasyonları nedeniyle RES'in en önemli diyet kaynağı olarak gösterilmektedir (5).

Nutrasötik olarak kabul edilen RES, genellikle Polygonum cuspidatum veya üzüm rizomundan ekstrakte edilen \%99 saflaştırılmış trans-RES formudur (19). Güvenli ve etkili kullanım dozu 1-5 g olarak belirtilmekle birlikte bireyler arasında farklı olumsuz yan etkilerinin görülebildiği de bildirilmiştir. Yapılan çalışmalarda RES atılımının, alındıktan sonraki ilk dört saat içinde gerçekleştiği gösterilmiştir $(20,21)$.

\section{Resveratrolün Emilimi ve Dokulara Taşınması}

Resveratrolün emiliminin büyük bir bölümü jejunumdan, az bir bölümü ise ileumdan gerçekleşmektedir. Bazolateral tarafa transport edilen resveratrolün çoğu, glukuronid ve sülfat formlarına dönüşmektedir. Tüm resveratrol ve konjugatlarının sadece \%6'sı barsak epitelini geçebilmektedir (20). Resveratrol besinlerde cis ve trans formlarinda bulunmaktadir. Glikozile olmuş formu 3-O- $\beta$-Dglukozid olarak isimlendirilmektedir. Resveratrolün glikolize olması onun enzimatik olarak oksidasyonunu önleyerek biyoyararlanımını arttırmaktadır. Barsak hücreleri sadece glikozile olmayan resveratrolü absorbe ettiği için emilim aşamasında glikozidaz enzimler gerekmektedir. Resveratrolün glikozid formu olan Trans-piseidin deglikozile edilebilmesi için ince barsakta laktaz florizin hidrolaz [Lactase phlorizin hydrolase (LPH)] ve sitozolik-§s-glukozidaz [Cytosolicßs-glucosidase (CBG)] enzimleri tarafindan gerçekleşmektedir. Deglikozilasyon sonrasında trans- 
Tablo 1. Besinlerdeki ve içeceklerdeki RES miktarı (7).

\begin{tabular}{lcc}
\hline Besin Kaynağı & Servis Miktarı & RES Miktarı (mg) \\
\hline Kırmızı Şarap & $100 \mathrm{~mL}$ & 0.19 \\
Beyaz Şarap & $100 \mathrm{~mL}$ & 0.085 \\
Kırmızı Şarap (Misket üzümü) & $100 \mathrm{~mL}$ & 3.02 \\
Şampanya & $100 \mathrm{~mL}$ & $9 \times 10^{-3}$ \\
Üzüm (Kırmızı) & $100 \mathrm{~g}$ & 0.47 \\
Üzüm (Yeşil) & $100 \mathrm{~g}$ & 0.02 \\
Çilek & $100 \mathrm{~g}$ & 0.35 \\
Yaban Mersini & $100 \mathrm{~g}$ & 0.248 \\
Bitter Çikolata & $100 \mathrm{~g}$ & 0.04 \\
Üzüm (Yeşil), Saf meyve suyu & $100 \mathrm{~mL}$ & $5.08 \times 10^{-3}$ \\
Yer fistığı & $100 \mathrm{~g}$ & 0.08 \\
\hline
\end{tabular}

piseid trans-resveratrole dönüşmektedir. Transresveratrol enterositlerde daha ileri metabolize edildiğinde, glukuronik konjugatına dönüşmektedir. Major glukuronat trans resveratrol-3-O- $\beta$-glukuronid olup Glukurokonjugat enterositlerden barsak lümenine salınmaktadır. Konjuge hale gelen RES'in kana geçişi ve vücutta dağılımı kolaylaşmaktadır. Karaciğer ve safra kesesi tarafindan filtrasyona uğrayan RES ve metabolitleri safra ve bağırsağa atıldıktan sonra geri emilime uğramaktadır. Karaciğerde glukuronatlanan RES’ün, karaciğer ve duedenumda sülfatasyonu gerçekleşir (Şekil 3) $(23,24)$. Resveratrolün atılımını plazmada bulunan resveratrol konsantrasyonu belirlemekle birlikte, üretilen ve atılan resveratrol miktarı arasında bir ilişki bulunmamaktadır. Çok az miktarda glikolize olmamış resveratrol idrarda bulunmaktadır $(20,22)$.

\section{Resveratrolün Kardiyovasküler Hastalıklar Üzerine Etkisi}

Bulaşıcı olmayan hastalıklardan biri olan KVH için önleyici ve koruyucu hizmetler planlanmalıdır. Kardiyovasküler hastalıklardan korunma ideal olarak gebelikte başlar ve yaşamın sonuna kadar sürer. Günlük uygulamada, koruma çalışmaları tipik olarak kanıtlanmış KVH’ı olan orta yaşlı veya yaşlı erkek ve kadınları veya ilk kez kardiyovasküler olay geliştirme riski yüksek olan bireyleri örneğin sigara, yüksek kan basıncı, diyabet veya dislipidemi gibi çoklu risk faktörlerini bir arada bulunduran erkek ve kadınları hedef alır. Gençlerde ve çok yaşlılarda ya da sadece orta veya hafif riski olanlarda KVH'dan korunma hala sinırlıdır (2). Ancak, davranış değişikliği, psikososyal risk faktörlerinin tedavisi, düzenli egzersiz yapmak, sigarayı bırakmak, sağlıklı beslenme alışkanlığı edinerek sağlıklı vücut ağırlığına ulaşmak ve bunu korumak, yüksek plazma düşük dansiteli lipoprotein kolesterol (LDL-K) seviyelerinin uygun aralıkta tutulmasını sağlamak, kan glukoz regülasyonunu sağlamak ve kan basıncını düzenleyici tedaviye başlamak gibi stratejilerin önemli yararları vardır $(2,25,27)$.

Temel olarak dünya genelinde halen var olan yanlış beslenme alışkanlıkları, sağlık durumundaki bozulmaların bir nedeni olarak görülmektedir. Bu nedenle, birey ve toplum düzeyinde besin alımını optimize etmek, sağlık bakımı ve hastalıkların önlenmesi için izlenmesi gereken bir stratejidir (26). Kardiyovasküler hastalıkların önlenmesinde ve tedavisinde doymuş yağ asidi, kolesterol ve sodyum içeriği düşük, tam tahıllı besinlerden, sebze ve meyvelerden zengin dengeli bir diyet önerilmektedir. $\mathrm{Bu}$ bağlamda Hipertansiyonu Önlemek için Diyet Yaklaşımları (Dietary Approaches to Stop Hypertension/DASH) ve Akdeniz Tipi Beslenme modellerinin KVH'ın önlenmesinde ve yönetiminde etkili olduğu oldukları kanıtlanmıştır $(28,29)$.

Resveratrol, hepatik 3-hidroksi-3-metil-glutaril-CoA (HMG-CoA) redüktazın (kolesterol biyogenezinde 


\section{Doku Dağılımı}

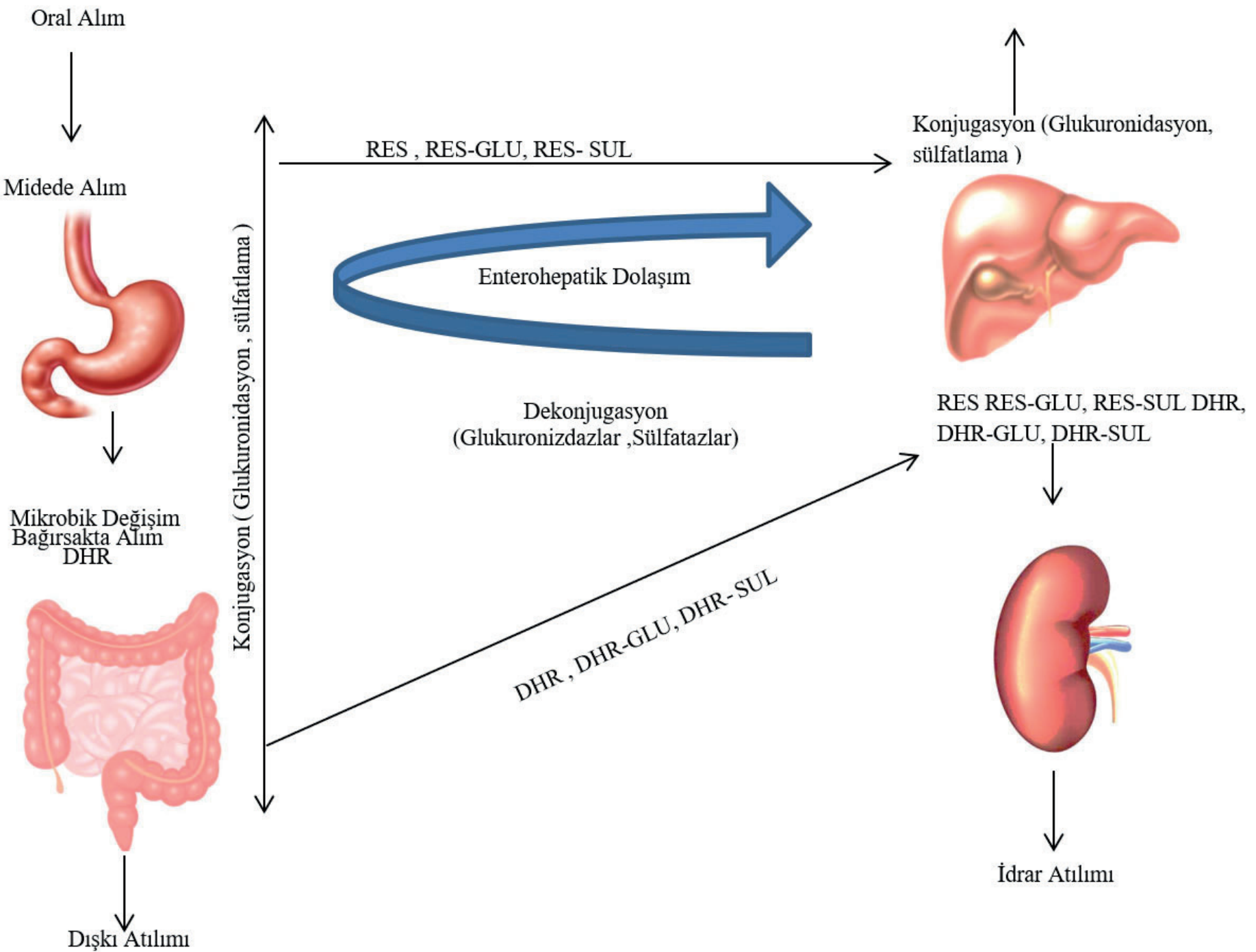

Şekil 3. RES'in metabolizması ve düzenlenmesi: RES temel olarak oral alımdan sonra ince bağırsakta emilir. Daha sonra bağırsak ve karaciğerdeki RES-GLU ve RES-SUL formlarına hızlı bir şekilde metabolize edilir. RES-GLU ve RES-SUL formları böbrek tarafından idrarla atılır. İnsan vücudunda sülfatazlar ve glukuronidazlar, konjuge edilmiş RES formlarını tekrar serbest RES formuna dönüştürebilir. Enterohepatik geri dönüşüm ayrıca safra yolu ile atılım ve bağırsakta yeniden emilimle de meydana gelir. Ayrıca, bağırsakta emilmeyen RES, DHR-GLU ve DHR-SUL türevlerine daha da metabolize edilebilen mikrobiyal metabolitlere, örneğin DHR'ye dönüştürülür. Son olarak, emilmeyen RES ve metabolitleri dışkıyla atılır. $D H R$, dihidroresveratrol; GLU, glukuronid; RES, resveratrol; SUL, sülfat (24).

yer alan bir enzim) mRNA ekspresyonunda azalması ve potansiyel olarak ters kolesterol taşınmasına yol açabilen ve lipit profilinde iyileşebilen sessiz bilgi düzenleyici faktör 2 ilgili enzim 1 (SIRT1) aktivasyonunu içeren mekanizma ile lipid profilini iyileştirmektedir. Resveratrolün kan basıncını azaltabileceği mekanizmalar; endotel nitrik oksit (NO) üretimindeki artış, endotel hücrelerinde artan SIRT1 ekspresyonu ile oksidatif hasarı ve azalmış kalsiyum akışını içermektedir. Resveratrolün insanlarda potansiyel antiinflamatuvar etkileri için mekanizma, SIRT1'in artan aktivasyonudur. Resveratrol, hayvanlarda ve kültürlenmiş hücrelerde SIRT1'in bilinen bir aktivatörüdür. Bu nedenle, resveratrolün SIRT1'in aktivitesini artırarak insanlarda inflamasyonu potansiyel olarak azaltabilmektedir. Resveratrolün vasküler sistem için NO üreten birincil enzim olan endotelyal nitrik oksit sentazın (eNOS) 


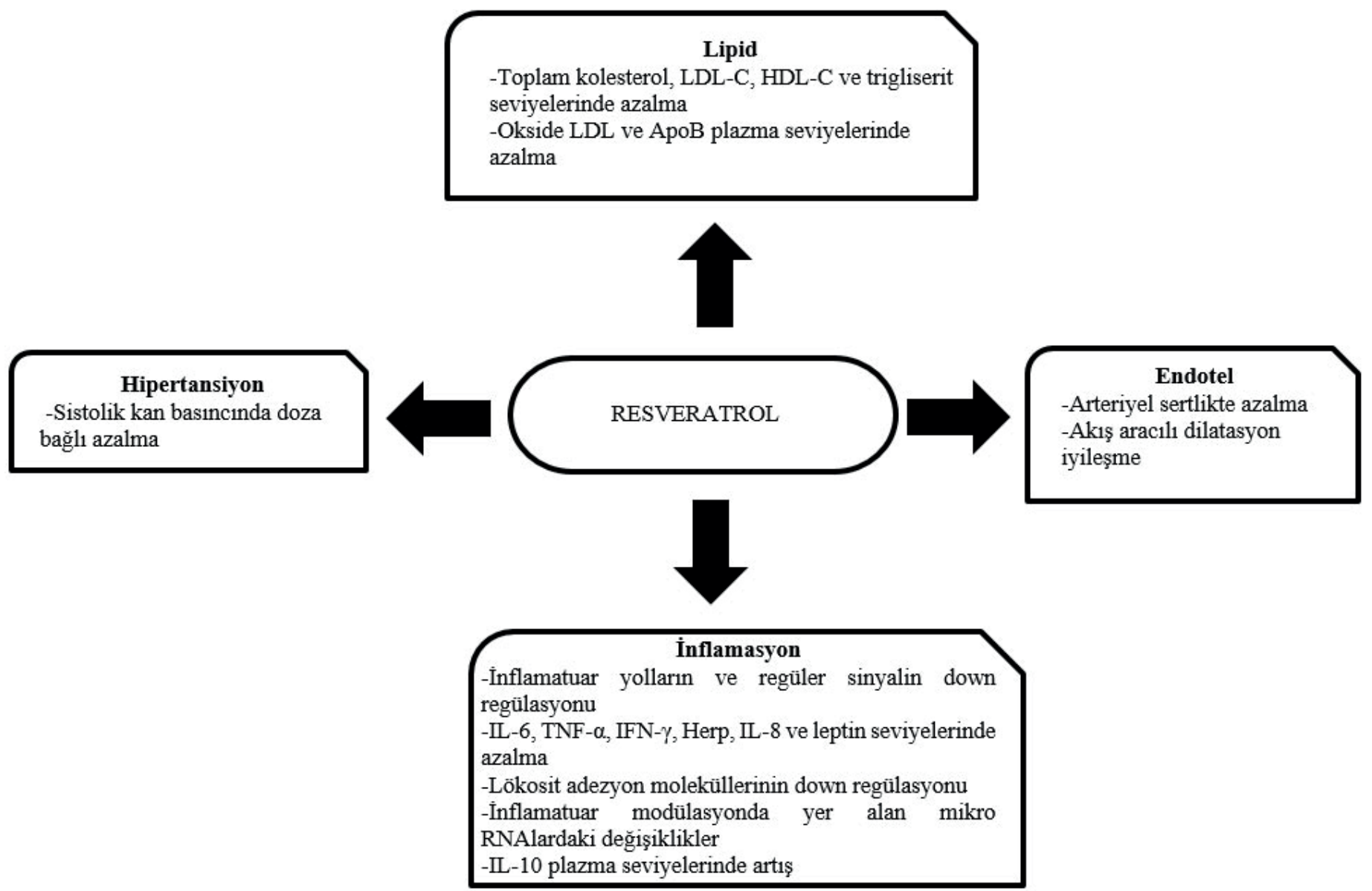

Şekil 4. Resveratrol içeren klinik çalışmalardan elde edilen bulguların özeti (30).

IL-6, İnterlökin-6 ;TNF- $\alpha$, Tümör nekroz faktörü alfa; IFN-ү, İnterferon gama; IL-8, İnterlökin-; , IL-10,İnterlökin-10; LDL-C, düşük dansiteli lipoprotein kolesterol; HDL-C, yüksek dansiteli lipoprotein kolesterol; LDL, lipoprotein; ApoB:apolipoprotein B

yukarı regülasyonu ve oksidatif stresi azaltmak için eNOS’un ayrışmasında azalma dahil olmak üzere endotel fonksiyonu üzerinde olumlu etkileri vardır (30).

Brezilya’da yapılan randomize, çaprazlama, çift kör, plasebo kontrollü bir çalışmada, başlangıçta endotel disfonksiyonu olan 45-65 yaş arası 24 hipertansif hastaya tek bir doz trans-resveratrol (300 mg) ve plasebo verildiğinde trans RES’in akut takviyesi kan basıncında herhangi bir değişikliğe yol açmazken, özellikle daha yüksek LDL-K düzeyine sahip olan hipertansif kadınlarda endotel fonksiyonda iyileşme sağladığı gösterilmiştir (13). Yapılan başka bir çalışmada ise yeni dislipidemi tanısı almış 20 ile 65 yaş arası sağlıklı gebe olmayan kadın ve erkek hastalara rastgele olarak iki ay boyunca $100 \mathrm{mg} /$ gün RES ve plasebo (sükroz 0.5 g/gün) desteği verilmiş ve RES desteğinin dislipidemili bireylerde toplam kolesterol ve triaçilgliserol konsantrasyonlarını önemli oranda azalttığı belirlenmiştir (31).

Japonya'da, çift-kör, randomize, plasebo kontrollü yapılan bir çalışmada ise tip 2 diyabetli 50 hastaya 12 hafta boyunca günlük $100 \mathrm{mg}$ RES tablet veya plasebo takviyesi verilmiş ve RES takviyesinin arteriyel sertliği oksidatif stresi azaltabileceği ve diyabetin neden olduğu ateroskleroz gelişimini önlemede yararlı olabileceği belirtilmiştir (32).

Randomize, plasebo kontrollü çapraz bir çalışmada, erkek ve kadınlardan oluşan toplam 45 fazla kilolu ve obez bireylere dört hafta boyunca rastgele siralı RES (günde $150 \mathrm{mg}$ ) veya plasebo kapsülleri verildiğinde, RES alımının, fazla kilolu ve hafif obez erkek ve kadınlarda kardiyovasküler sağlık ile ilgili metabolik risk belirleyicilerini değiştirmediği saptanmıştır 
(33). Randomize, çift kör, plasebo kontrollü bir klinik çalışmada ise non-alkolik yağlı karaciğer hastalığı tanısı almış 50 hastaya 12 hafta boyunca 500 mg RES veya plasebo kapsülü verildiğinde RES takviyesinin, lipit profili ve kan basıncı üzerinde olumlu bir etkisinin olmadığı sonucuna varılmıştır (34).

Şarap ekstraktı veya üzüm, damar duvarında 3',5'monofosfat (cGMP) seviyesini arttırmaktadır. Hem relaksasyon hem de cGMP'de artış NG-monometil-Larjinin ya da NG-nitro-L-arjinin (endotelyuma bağlı gevşetici faktörün sentezinin kompetetif inhibitörü) tarafından ters çevrilmektedir. Üzümdeki ürünler tarafından indüklenen vazorelaksasyona NO-cGMP yolu aracılık etmektedir. Vazorelaksasyonda NO'nun doğrudan rolü resveratrol ile muame edilen pulmoner arter endotel hücre kültüründe nitrik oksit sentaz (NOS) etkinliğinde artış bulunduğunda gösterilmiştir. Resveratrolün NOS üretimini etkileyerek kardiyoprotektif etki gösterdiği de saptanmıştır (35). Shen et al. (36) ratlarda iskemi/reperfüzyon (I/R) hasarında resveratrolün kardiyoprotektif etkilerini miyokardiyal nitrik oksit (NO) ve malondialdehit (MDA) parametreleri ile değerlendirmişlerdir. Resveratrol, I/R hasarı uygulanan ratlarda kalbi korumaktadır. Bu etki, NO üretiminin arttırılması ve antioksidan etkinliği ile ilgili olabilir.

Yapılan bir araştırmada NO inhibitörü olan nitroL-arjinin metil esterinin (L-NAME), resveratrolün yararlı etkilerini ortadan kaldırdığı gösterilmiştir. (35). Brito et al. (37) sığır aortik endotel hücresinde peroksinitritin aracılık ettiği endotel hücre toksisitesinde resveratrolün değişik doz ve sürelerinin etkisini hücre canlılığı, okside ve redükte glutatyon düzeyi ile ilişkisini incelemişlerdir. Resveratrolün peroksinitritin indüklediği oksidatif strese karşı hücre içi indirgenmiş glutatyon (GSH) düzeyini arttırarak kardioprotektif etki sağladığını göstermişlerdir. Altun et al. (38) glutatyon peroksidaz, süperoksit dismutaz (SOD), katalaz, NO ve nitrotirozin ile resveratrol'ün in vitro insan umblikal ven endotel hücrelerinde hipoksireoksijenasyon hasarına karşı koruyucu etkilerini değerlendirmişlerdir. $\mathrm{Bu}$ araştırmada, hipoksi reoksijenasyon ile nitrik oksit konsantrasyonunun, katalaz ve SOD seviyelerinin değişmediğini, resveratrol'ün 10, 50, $100 \mathrm{mM}$ konsantrasyonlarında ROS oluşumunu azalttığını göstermişlerdir. Csiszar et al. (39) resveratrolün insan koroner arter endotel hücrelerinde TNF-a'nın indüklediği nükleer faktörü kappa B (NF-kB) aktivasyonunu ve enflamatuar gen ekspresyonunu doza bağlı olarak inhibe ettiğini saptamışlardır.

Resveratrol, antiapoptatik sinyali indükleyerek kalbi korumaktadır. Resveratrolün domuz koroner arterleri üzerine etkisi incelediğinde, mitojenle etkinleşen protein kinaz (MAPK) etkinliğinin inhibe olduğu; ERK1/2, Jun N-terminal kinaz (JNK-1) ve p38MAPK'ın fosforilasyonunu azalttığı rapor edilmiştir. Benzer bir çalışmada, resveratrolün endotelin-1 aracılığıyla protein tirozin fosforilasyonunu azalttığı, iskemikreperfüze kalpte apoptotik kardiyomiyositleri azalttığı ve anti-apoptotik etkileri gösterilmiştir (35). Resveratrol oksidatif stresin indüklediği apoptotik hücre ölümünü önleyerek ve hidrojen peroksit $\left(\mathrm{H}_{2} \mathrm{O}_{2}\right)$ yakalayarak vasküler oksidatif strese direnci arttırmaktadır. Sıçan koroner arter endotel hücresinde resveratrol glutatyon peroksidaz-1 ve hem oksijenaz-1 ekspresyonunu arttırarak antioksidan etkilerini göstermektedir (40).

\section{SONUÇ VE ÖNERİLER}

Resveratrolün hipertansiyon, obezite, inflamasyon, diyabet ve dislipidemi üzerindeki yararlı etkileri göz önünde bulundurulduğunda KVH'ın önlenmesinde ve tedavisinde RES'in kullanılması farklı bir farmakolojik yaklaşım olabilir. Resveratrolün etkinliğine ilişkin literatürde bazı farklılıklar görülmesine rağmen, birçok faydalı etkiye sahip olmasından dolayı, KVH'ın önlenmesinde veya tedavisine katkıda bulunma olasılığı yüksektir. Antiinflamatuvar, antioksidan ve anti-apoptotik etkileri olan resveratrolün kardiyovasküler hastalıklarının patofizyolojisinde oksidatif hasara karşı koruma yeteneği gösterilmiş olmasına rağmen, hücresel ve biyokimyasal mekanizmaları tam olarak aydınlatılamamıştır. Reaktif oksijen ürünleri, 
iskemi/reperfüzyon hasarında önemli olduğu için antioksidanlar hücre hasarını iyileştirmede kullanılmaktadır. Kardiyovasküler hastalıklarda oluşan oksidatif stresin iyileştirilmesinde kullanılan antioksidanlar yeni terapötik yaklaşımlara $1 s ̧ ı$ tutabilir. Çok sayıda makaleye ve klinik çalışmaya rağmen, kardiyovasküler hastalıklarda resveratrolün etkinliğini daha iyi açıklayabilmek için, bu maddenin olası sağlığı iyileştirici etkilerini doğrulamak ve hem etkililiği hem de güvenliği ve olası terapötik potansiyeli belirlemek için randomize, çift kör, plasebo kontrollü çalışmalar olmak üzere daha fazla klinik çalışmaya ihtiyaç duyulmaktadır.

Çıkar çatışması - Conflict of interest: Yazarlar çlkar çatışması olmadığını beyan ederler. - The authors declare that they have no conflict of interest.

\section{KAYNAKLAR}

1. Ciraci E, Ak K, Tetik S. Evaluation of thrombinantithrombin complex in patients with type-II diabetic coronary artery disease. IJBCS. 2020;9(2):46-56.

2. European Guidelines on cardiovascular disease prevention in clinical practice (version 2012). Turk Kardiyol Dern Ars. 2012;40(3):1-76.

3. Amri A, Chaumeil J, Sfar S, Charrueau C. Administration of resveratrol: What formulation solutions to bioavailability limitations?. J Control Release. 2012;158(2):182-93.

4. Salehi B, Mishra AP, Nigam M, Sener B, Kilic M, SharifiRad M, et al. Resveratrol: A double-edged sword in health benefits. Biomedicines. 2018;6(3):1-20.

5. Biesalski HK. Polyphenols and inflammation: basic interactions. Current Opinion in Clinical Nutrition \& Metabolic Care. 2007;10(6):724-8.

6. Pallàs M, Porquet D, Vicente A, Sanfeliu C. Resveratrol: new avenues for a natural compound in neuroprotection. Current Pharmaceutical Design. 2013;19(38):6726-31.

7. Rouse M, Egan JM. Resveratrol in aging and age-related diseases. In Ram JL, Conn PM, editors. Conn's Handbook of Models for Human Aging. 2nd ed. USA: Academic Press; 2018. 1133-1142 p.

8. Pezzuto JM. Resveratrol: twenty years of growth, development and controversy. Biomol Ther. 2019;27(1):1-14.

9. Li M, Kildegaard KR, Chen Y, Rodriguez A, Borodina I, Nielsen J. et al. De novo production of resveratrol from glucose or ethanol by engineered Saccharomyces cerevisiae. Metab Eng. 2015;32:1-11.

10. Chu LM, Lassaletta AD, Robich MP, Sellke FW. Resveratrol in the prevention and treatment of coronary artery disease. Curr Atheroscler Rep. 2011;13:439-46.

11. Liao Z, Liu D, Tang L, Yin D, Yin S, Lai S, et al. Long-term oral resveratrol intake provides nutritional preconditioning against myocardial ischemia / reperfusion injury: Involvement of VDAC1 down regulation. Mol Nutr Food Res. 2015;59(3):454-64.

12. Li J, Xie C, Zhuang J, Li H, Yao Y, Shao C, et al. Resveratrol attenuates inflammation in the rat heart subjected to ischemia-reperfusion: Role of the TLR4/NF- $\kappa B$ signaling pathway. Mol Med Rep. 2015;11(2):1120-6.

13. Marques BCAA, Trindade M, Aquino JCF, Cunha AR, Gismondi RO, Neves M. Beneficial effects of acute transresveratrol supplementation in treated hypertensive patients with endothelial dysfunction. Clin Exp Hypertens. 2018;40(3):218-23.

14. Langcake P, Pryce RJ. A new class of phytoalexins from grapevines. Experientia. 1977;33(2):151-2.

15. Becker L, Bellow S, Carré, V, Latouche G, Poutaraud A, Merdinoglu D, et al. Correlative analysis of fluorescent phytoalexins by mass spectrometry imaging and fluorescence microscopy in grapevine leaves. Anal Chem. 2017;89(13):7099-106.

16. Chitarrini G, Zulini L, Masuero D, Vrhovsek U. Lipid, phenol and carotenoid changes in 'Bianca' grapevine leaves after mechanical wounding: a case study. Protoplasma. 2017;254(6):2095-106.

17. Goutham G, Manikandan R, Beulaja M, Thiagarajan R, Arulvasu C, Arumugam M, et al. A focus on resveratrol and ocular problems, especially cataract: From chemistry to medical uses and clinical relevance. Biomed Pharmacother. 2017;86:232-41.

18. Sparvoli F, Martin C, Scienza A, Gavazzi G, Tonelli C. Cloning and molecular analysis of structural genes involved in flavonoid and stilbene biosynthesis in grape (Vitis vinifera L.). Plant Mol Biol. 1994;24(5):743-55.

19. Chachay VS, Kirkpatrick CM, Hickman IJ, Ferguson M, Prins JB, Martin, JH. Resveratrol-pills to replace a healthy diet?. Br J Clin Pharmacol. 2011;72(1):27-38.

20. Signorelli P, Ghidoni R. Resveratrol as an anticancer nutrient: molecular basis, open questions and promises. J Nutr Biochem. 2005;16(8):449-66.

21. Ramírez-Garza, SL, Laveriano-Santos EP, MarhuendaMuñoz M, Storniolo CE, Tresserra-Rimbau A, VallverdúQueralt A, Lamuela-Raventós RM. Health effects of resveratrol: Results from human intervention trials. Nutrients. 2018;10(12):1-18.

22. Cottart CH, Nivet-Antoine V, Laguillier-Morizot C, Beaudeux JL. Resveratrol bioavailability and toxicity in humans. Mol Nutr Food Res. 2010;54(1):7-16. 
23. Hoshino J, Park EJ, Kondratyuk TP, Marler L, Pezzuto JM, van Breemen RB, et al. Selective synthesis and biological evaluation of sulfate-conjugated resveratrol metabolites. J Med Chem. 2010;53(13):5033-43.

24. Bird JK, Raederstorff D, Weber P, Steinert, RE. Cardiovascular and antiobesity effects of resveratrol mediated through the gut microbiota. Advances in Nutrition. 2017;8(6):839-49.

25. Piepoli MF, Hoes AW, Agewall S, Albus C, Brotons C, Catapano AL, et al. 2016 European Guidelines on cardiovascular disease prevention in clinical practice: The Sixth Joint Task Force of the European Society of Cardiology and Other Societies on Cardiovascular Disease Prevention in Clinical Practice (constituted by representatives of 10 societies and by invited experts) Developed with the special contribution of the European Association for Cardiovascular Prevention \& Rehabilitation (EACPR). Eur Heart J. 2016;37(29):231581.

26. Ordovas JM. Gene-diet interactions and cardiovascular diseases: Saturated and monounsaturated fat. In: Caterina DR, Martinez JA, editors. Principles of Nutrigenetics and Nutrigenomics. 1st ed. Madrid: Academic Press; 2020. 211-222 p.

27. Richter CK, Skulas-Ray AC, Fleming JA, Link CJ, Mukherjea R, Krul ES, et al. Effects of isoflavonecontaining soya protein on ex vivo cholesterol efflux, vascular function and blood markers of CVD risk in adults with moderately elevated blood pressure: a dose-response randomised controlled trial. Br J Nutr. 2017;117(10):1403-13.

28. Thuc LC, Teshima Y, Takahashi N, Nishio S, Fukui A, Kume $\mathrm{O}$, et al. Inhibition of $\mathrm{Na}+-\mathrm{H}+$ exchange as a mechanism of rapid cardioprotection by resveratrol. Br J Pharmacol. 2012;166(6):1745-55.

29. Wu JM, Hsieh TC. Resveratrol: a cardioprotective substance. Ann N Y Acad Sci. 2011;1215(1):16-21.

30. Dyck GJ, Raj P, Zieroth S, Dyck JR, Ezekowitz JA. The effects of resveratrol in patients with cardiovascular disease and heart failure: a narrative review. Int J Mol Sci. 2019;20(4):904.
31. Simental-Mendía LE, Guerrero-Romero, F. Effect of resveratrol supplementation on lipid profile in subjects with dyslipidemia: A randomized double-blind, placebocontrolled trial. Nutrition. 2019;58:7-10.

32. Imamura H, Yamaguchi T, Nagayama D, Saiki A, Shirai K, Tatsuno, I. Resveratrol ameliorates arterial stiffness assessed by cardio-ankle vascular index in patients with type 2 diabetes mellitus. Int Heart J. 2017;58(4):577-83.

33. Made VDSM, Plat J, Mensink RP. Resveratrol does not influence metabolic risk markers related to cardiovascular health in overweight and slightly obese subjects: a randomized, placebo-controlled crossover trial. PLoS one. 2015;10(3):1-13.

34. Faghihzadeh F, Adibi P, Hekmatdoost A. The effects of resveratrol supplementation on cardiovascular risk factors in patients with non-alcoholic fatty liver disease: a randomised, double-blind, placebo-controlled study. Br J Nutr. 2015;114(5):796-803.

35. Das DK, Maulik N. Resveratrol in cardioprotection: a therapeutic promise of alternative medicine. Mol Interv. 2006;6(1):36-47.

36. Shen M, Jia GL, Wang YM. Cardioprotective effect of resvaratrol pretreatment on myocardial ischemiareperfusion induced injury in rats. Vascul Pharmacol. 2006;45(2):122-6.

37. Brito PM, Mariano A, Almeida LM, Dinis TC. Resveratrol affords protection against peroxynitrite-mediated endothelial cell death: A role for intracellular glutathione. Chem Biol Interact. 2006;164(3):157-66.

38. Altun Z, Egrilmez MY, Bicer NY, Genc K, Genc S, Sayin $\mathrm{O}$, et al. Protective effects of resveratrol against in vitro hypoxia reoxygenation injury in human umbilical vein endothelial cells. FEBS J. 2007;274:362.

39. Csiszar A, Smith K, Labinskyy N. Resveratrol attenuates TNF-a induced activation of coronary arterial endothelial cells: role of NF- $\kappa$ B inhibition Am J Physiol Heart Circ Physiol. 2006;291:1694-9.

40. Ungvari Z, Orosz Z. Resveratrol increases vascular oxidative stress resistance. Am J Physiol Heart Circ Physiol. 2007;292:H2417-24. 